Full length article

\title{
Population genetic structure of the parasite Anisakis simplex (s. s.) collected in Clupea harengus L. from North East Atlantic fishing grounds
}

\section{Simonetta Mattiucci ${ }^{\mathrm{a}, *}$, Lucilla Giulietti ${ }^{\mathrm{a}, \mathrm{b}}$, Michela Paoletti ${ }^{\mathrm{a}, \mathrm{b}}$, Paolo Cipriani ${ }^{\mathrm{a}, \mathrm{b}}$, Melanie Gay ${ }^{\mathrm{c}}$, Arne Levsen $^{\mathrm{d}}$, Regina Klapper ${ }^{\mathrm{e}}$, Horst Karl ${ }^{\mathrm{f}}$, Miguel Bao ${ }^{\mathrm{g}}$, Graham J. Pierce ${ }^{\mathrm{g}, \mathrm{h}, \mathrm{i}}$, Giuseppe Nascetti ${ }^{\mathrm{b}}$}

a Department of Public Health and Infectious Diseases, Section of Parasitology, "Sapienza-University of Rome", Rome, Italy

b Department of Ecological and Biological Sciences (DEB), "Tuscia University", Viterbo, Italy

${ }^{\mathrm{c}}$ French Agency for Food, Environmental and Occupational Health and Safety (Anses), Laboratory for Food Safety, Boulogne-sur-mer, France

d National Institute of Nutrition and Seafood Research (NIFES), Bergen, Norway

e Goethe-University, Institute for Ecology, Evolution and Diversity, Senckenberg Biodiversity and Climate Research Centre, Senckenberg Gesellschaft für Naturforschung Frankfurt/Main, Germany

${ }^{\mathrm{f}}$ Department of Safety and Quality of Milk and Fish Products, Federal Research Institute for Nutrition and Food, Max-Rubner-Institut, Hamburg, Germany

$\mathrm{g}$ School of Biological Sciences, University of Aberdeen, Aberdeen, United Kingdom

h CESAM \& Departamento de Biologia, Universidade de Aveiro, Aveiro, Portugal

${ }^{\mathrm{i}}$ Instituto de Investigaciones Marinas (CSIC), Eduardo Cabello 6, 36208, Vigo, Spain

\section{A R T I C L E I N F O}

\section{Keywords:}

Clupea harengus

Herring stocks

North East Atlantic Ocean

Anisakis simplex (sensu stricto)

Genetic marker

mtDNA $\operatorname{cox} 2$

Population genetics

\begin{abstract}
A B S T R A C T
The Atlantic herring is a schooling, pelagic species that inhabits both sides of the North Atlantic Ocean. Herring stock identification is usually based on several approaches, including fish meristic characters, population genetic analysis and the use of parasite species composition. A total of 654 Anisakis spp. larvae collected from herring of four fishing grounds in the Norwegian Sea, Baltic Sea, North Sea, and the English Channel off the French coast, was identified to species level using diagnostic allozymes and sequence analysis of EF1 $\alpha-1$ nDNA and the mtDNA cox 2 genes. Population genetic differentiation of Anisakis simplex (s. s.) among the different fishing areas was estimated, at the intraspecific level, on the basis of mtDNA $\operatorname{cox} 2$ sequences analysis. Spatial comparison based on molecular variance analysis and $F_{s t}$ values was performed for the collected specimens (among regions). Haplotype network construction showed relevant differences in haplotype frequencies between samples of $A$. simplex (s. s.) from the different geographical areas. Results indicate a genetic sub-structuring of $A$. simplex (s. s.) obtained from herring in different areas, with the population from the Norwegian Sea being the most differentiated one, and with North Sea and Baltic Sea populations being most similar. The population genetic structure of $A$. simplex (s. s.) was in accordance with the herring population genetic structure throughout the host's geographical range in the NE Atlantic. Results suggest that mtDNA cox 2 is a suitable genetic marker for $A$. simplex (s. s.) population genetic structure analysis and a valuable tool to elucidate the herring stock structure in the NE Atlantic Ocean.
\end{abstract}

\section{Introduction}

The Atlantic herring Clupea harengus Linnaeus, 1758 is a schooling, pelagic species that inhabits both sides of the North Atlantic Ocean. In North East (NE) Atlantic waters, herring distribution ranges from the northern Bay of Biscay to Greenland, and East into the Barents Sea, where it represents one of the commercially most important fish species (ICES, 2006). Atlantic herring stocks have fluctuated enormously in the past, as many stocks of other pelagic teleosts have experienced (Parmanne et al., 1994; Toresen and Osvedt, 2000; ICES, 2007; Reiss et al., 2009; Dickey-Collas et al., 2010; Huse, 2015). Due to over-exploitation of stocks in the 1970s, harvest levels of this species were reduced to rebuild the stocks (Herdson and Priede, 2010). Since then, $C$. harengus biomass has increased, but it needs continuous monitoring in order to prevent further overfishing and depletion of less productive stocks (Herdson and Priede, 2010).

Herring population dynamics are complex and different stocks often display variation in life history and spawning season (Bekkevold et al., 2005; Mariani et al., 2005; Clausen et al., 2007; Reiss et al., 2009). Juveniles and adults perform extensive seasonal north-south and

\footnotetext{
* Corresponding author at: Department of Public Health and Infectious Diseases, Section of Parasitology, "Sapienza-University of Rome", P.le Aldo Moro, 5 - 00185 Rome, Italy.

E-mail address: simonetta.mattiucci@uniroma1.it (S. Mattiucci).
} 
inshore-offshore migrations for feeding, spawning, and wintering (Clausen et al., 2007). In addition, extensive mixing between spawning stock components occurs during feeding aggregations, among juvenile stages, and sometimes during overwintering (Brophy and Danilowicz, 2002; Reiss et al., 2009). Thus, herring spawning components maintain significant levels of reproductive isolation, possibly determined by selective differences among spawning and/or larval habitats (Limborg et al., 2012).

Despite the long tradition of research on general biology, ecology and population genetic structure of $C$. harengus, there is no consensus as to how herring populations are spatially and temporally structured (Mariani et al., 2005; Reiss et al., 2009). The identification and characterization of herring stocks were usually based on holistic approaches, including fish morphometric and meristic characters (morphological analysis, otolith analysis, hatch type) (Ryman et al., 1984; Hatfield et al., 2005; Mariani et al., 2005; André et al., 2011), fish genetics (allozymes, DNA microsatellite loci, mtDNA RFLP) (Ryman et al., 1984; Shaw et al., 1999; Hauser et al., 2001; Jørgensen et al., 2005; Mariani et al., 2005; Cross et al., 2007; Ruzzante et al., 2006; Pampoulie et al., 2015), and other fish population parameters (e.g., biological tags, recruitment patterns, size-at-age, spawning time and spawning location) (Ryman et al., 1984; Toresen and Osvedt, 2000; Bekkevold et al., 2005; Jørgensen et al., 2005; Clausen et al., 2007; Bierman et al., 2010; Dickey-Collas et al., 2010; André et al., 2011; Geffen et al., 2011; FEAS, 2015).

However, although a large number of $C$. harengus stocks have been assessed throughout the NE Atlantic, the relationships between them still remains uncertain. Within the North Sea herring stock, four populations (Shetland/Orkney, Buchan, Banks, and Downs) were distinguished based on meristic parameters, migration routes and nursery area (Reiss et al., 2009; Dickey-Collas et al., 2010; ICES, 2016a). However, this subdivision was not supported by recent genetic studies based on DNA microsatellites loci, that indicate genetically indistinguishable spawning aggregations of herring in the North Sea (Mariani et al., 2005; Ruzzante et al., 2006; Reiss et al., 2009), thereby reinforcing the current management of North Sea herring as a single unit, namely the North Sea autumn spawning stock (NSAS) (ICES, 2016a), distributed in Divisions IVa, IVb, IVc and Divisions IIIa and VIId (see Fig. 1). However, based on DNA microsatellite analysis, Mariani et al. (2005) found a weak but significant genetic differentiation between the herring population in the English Channel (English Channel winter spawning Downs) and the remaining North Sea populations, which was already taken into account by a sub-TAC (sub-Total Allowable Catches) for Divisions IVc and VIId within the North Sea TAC (Total Allowable Catches) (ICES, 2016a) (see Fig. 1).

In contrast to the North Sea stock, the western Baltic spring spawning herring stock (WBSS) comprises several genetically distinct populations spawning in Divisions IIIa, IIIb, and IIIc (Rügen herring, local autumn spawning Fehmarn herring, herring from the Kattegat and Inner Danish waters, and potentially other Western Baltic herring stocks) (Bekkevold et al., 2005; ICES, 2016b). Along the Scandinavian peninsula, the Norwegian spring spawning herring stock (NSS) is currently distributed from off south-west Norway to the Barents Sea, and across the Norwegian Sea up to the eastern coast of Iceland (Subareas I and II, Fig. 1) (Levsen and Lunestad, 2010; Pampoulie et al., 2015; ICES, 2016c).Metazoan parasites are commonly used as biological tags for fish stock discrimination, allowing to gain information on the biology, individual origin, intraspecific population dynamics, as well as migration and life history of actual fish host species (Parmanne et al., 1994; MacKenzie, 2002; Klimpel et al., 2004; Hatfield et al., 2005; Cross et al., 2007; Levsen and Lunestad, 2010; Karl and Levsen, 2011; Mattiucci et al., 2014a; Münster et al., 2015; Timi and Mackenzie, 2015; Klapper et al., 2016). Among metazoan parasites, Anisakis spp. larvae are considered suitable biological tags for fish stock identification, as long as their geographical distribution and life cycle are known, and the parasites' residence time within the host is sufficiently long to

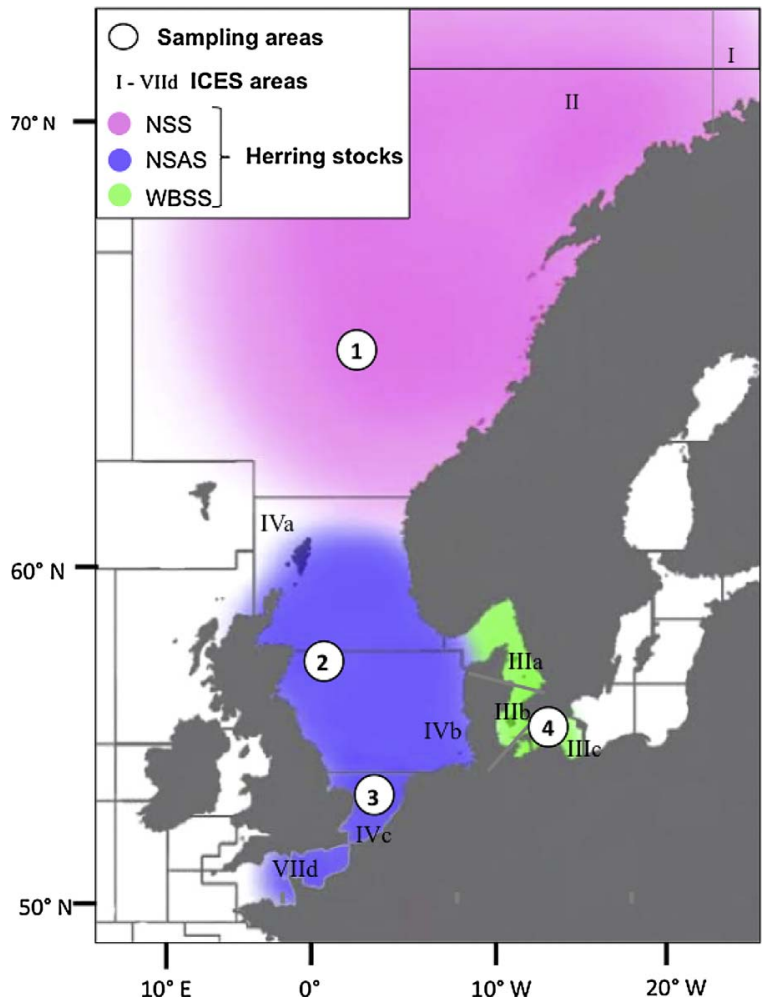

Fig. 1. Sampling localities of the C. harengus from the North East Atlantic: 1. Norwegian Sea $\left(64^{\circ} 41^{\prime} \mathrm{N} 00^{\circ} 47^{\prime} \mathrm{E}\right), 2$. North Sea $\left(54^{\circ} 42^{\prime} \mathrm{N} 0^{\circ} 44^{\prime} \mathrm{E}\right)$, 3. English Channel $\left(50^{\circ} 26^{\prime} \mathrm{N} 1^{\circ} 19^{\prime}\right.$ E), 4. Baltic Sea $\left(54^{\circ} 24^{\prime} \mathrm{N} 13^{\circ} 42^{\prime} \mathrm{E}\right)$. Different colours identify herring stock units (Norwegian spring spawning herring stock (NSS) in pink; North Sea autumn spawning herring stock (NSAS) in blue; Western Baltic spring spawning herring stock (WBSS) in green), according to ICES (2007, 2016a, 2016b). (For interpretation of the references to colour in this figure legend, the reader is referred to the web version of this article.)

be compared with the lifespan of the fish host (Mattiucci et al., 2014a). Clupea harengus represents a paratenic/transport host of parasite of the genus Anisakis, suitable for the transmission and completion of its complex life cycle (Mattiucci et al., 2014a). In the northern hemisphere, the most prevalent species of the genus Anisakis is represented by Anisakis simplex (s. s.) (Mattiucci and Nascetti, 2008). The life cycle of this parasite in the NE Atlantic Ocean involves various whale species as definitive host cetacean (whales, dolphins and porpoises), crustacean species (Crustacea, Euphausiacea) as main intermediate host, and numerous fish species, including herring, as intermediate/paratenic host, transferring the larvae from krill to cetaceans (Anderson, 2000; Levsen and Lunestad, 2010; Mattiucci et al., 2017). In the past, A. simplex (s. 1.) larvae have successfully been used as biological tags to investigate several populations of Clupea harengus in the NE Atlantic (BeverleyBurton and Pippy, 1977; Chenoweth et al., 1986; MacKenzie and Hemmingsen, 2005). The parasite-based methodology (including parasite community structure of the fish species along its geographical distribution, parasitic infection levels and genetic/molecular characterization of parasite species) was employed in a few areas of the NE Atlantic as an efficient tool to deepen knowledge about different herring stock components (Hatfield et al., 2005; Cross et al., 2007; Levsen and Lunestad, 2010; Grohsler et al., 2013).

On the other hand, the spatial structure of a parasite population may also reflect the population genetic structure of its hosts. Generally, parasites may be used to help elucidate evolutionary processes of their hosts. For example, phylogeographic information of the host may be highlighted by a higher evolutionary resolution of its parasites (Nieberding et al., 2004). It was also suggested that if a parasite has a similar or more complex genetic structure compared to its host, then the genotypes/haplotype of the parasite species can be used to assign hosts 
to their population of origin with higher accuracy than by using the host's genotype alone (Criscione et al., 2005; Froeschke and Von der Heyden, 2014). Studying the population genetic structure of a parasite species along the geographical range of its fish host was recently applied to infer knowledge about the population genetic structure of the fish host (Baldwin et al., 2011; Klapper et al., 2016).

Among the molecular/genetic markers so far available, mitochondrial genes are considered most suitable to assess population genetic structure of a parasite species and to infer phylogeographic studies, due to their higher rate of evolution (Froeschke and Von der Heyden, 2014).

The objectives of this study were: $i$ ) to identify Anisakis spp. larvae isolated from herring from different fishing grounds in the NE Atlantic Ocean (i.e. Norwegian Sea, North Sea, English Channel and Baltic Sea) to species level through a multilocus approach; ii) to study the population genetic structure of $A$. simplex (s. s.) in herring among fishing grounds, as inferred from the polymorphic mitochondrial gene mtDNA cox2; iii) to analyse Anisakis simplex (s. s.) populations to elucidate eventual genetic differences among various herring stocks.

\section{Materials and methods}

\subsection{Fish and parasites sampling}

A total of 654 larvae of Anisakis spp. were collected from 265 individual herring caught at four fishing grounds of the North East Atlantic Ocean, i.e. the Norwegian Sea $(n=228)$, North Sea $(n=129)$, English Channel $(n=181)$ and Baltic Sea $(n=116)$ (Table 1 and Fig. 1). The herrings were collected during 2013-2015 within the framework of the EU FP7 Project PARASITE (GA no. 312068), and subsequently examined for nematode parasites at the following laboratories: Laboratory for Food Safety of French Agency for Food, Environmental and Occupational Health and Safety (Anses), Boulognesur-mer, France; National Institute of Nutrition and Seafood Research (NIFES), Bergen, Norway; Department of Safety and Quality of Milk and Fish products, Federal Research Institute for Nutrition and Food, Max Rubner-Institute, Hamburg, Germany; Oceanlab, School of Biological Sciences, University of Aberdeen, Aberdeen, United Kingdom. For a full description of the methodology used to detect nematode parasites and the epidemiological data recorded for the fish specimens, see Levsen et al. (2017) (present issue).

Nematodes were counted and identified to the genus level by using an optical microscope according to the diagnostic morphological keys (sensu Berland, 1961). Collected nematodes were stored at $-70^{\circ} \mathrm{C}$ before further identification to the species level; they were then delivered in frozen condition to the Section of Parasitology of the Department of Public Health and Infectious Diseases (Sapienza - University of Rome) for their genetic/molecular identification. Part of those larval specimens recovered from herrings of some geographical areas belongs to the BioBank of the Project PARASITE. Only nematodes belonging to the genus Anisakis were considered in this study, and thus genetically identified to species level.

\subsection{Genetic/molecular identification of Anisakis spp. larvae from herring}

Individual multilocus genotyping of the 654 sampled individuals of Anisakis spp. (Fig. 1, Table 1) was obtained by using three distinct classes of molecular markers: allozymes, sequences analysis of nuclear (elongation factor EF1 $\alpha-1$ nDNA) and mitochondrial (mtDNA cox2) genes.

Multilocus allozyme electrophoresis (MAE) was performed to analyse three allozyme loci of diagnostic value for Anisakis spp. (Mattiucci et al., 2014b): adenylate kinase (Adk-2, EC 2.7.4.3) and leucine-alanine peptidase (Pep C-1, Pep C-2, EC 3.4.11). The procedures used for those allozymes are those previously detailed in Mattiucci et al. (2014b).

Larval tissue homogenates, obtained from each larva during the MAE, were preserved at $-20^{\circ} \mathrm{C}$ and subsequently used to obtain genomic DNA extracts of each examined individual. The total DNA was extracted using the Quick-gDNA MiniPrep (column format) by Zymo Research from $2 \mathrm{mg}$ of homogenized tissue from each single nematode following the manufacture's protocol. DNA obtained was quantified by using the Qubit ${ }^{\mathrm{TM}}$ dsDNA HS Assay Kit with Qubit 2.0 (Invitrogen $^{\mathrm{TM}}$ ). For sequencing the mtDNA cox 2 gene, PCR amplification was performed using the primers, 211F (5'-TTTTCTAGTTATATAGATTGRTTYAT- $3^{\prime}$ ) and 210R (5'-CACCAACTCTTAAAATTA TC-3') (Mattiucci et al., 2014b). Polymerase chain reaction (PCR) was carried out according to the previously described procedures (Mattiucci et al., 2014b). As reported in Table 2, a subsample of 160 specimens (40 individuals per area) of the Anisakis spp. genetically characterized at the allozyme level and sequenced at mtDNA cox2, were also tested by sequencing the elongation factor EF1 $\alpha-1 \mathrm{nDNA}$, according to the procedure reported in Mattiucci et al. (2016). The elongation factor (EF1 $\alpha-1$ nDNA) nuclear gene was amplified using the primers EF-F (5'-TCCTCAAGCGTTGTTATCTGTT-3') and EF-R (5'-AGTTTTGCCACTAGCGGTTCC-3') according to Mattiucci et al. (2016). The PCR was carried out in a $25 \mu \mathrm{L}$ volume containing $0.5 \mu \mathrm{L}$ of each primer $10 \mathrm{mM}, 2.5 \mu \mathrm{L}$ of $\mathrm{MgCl} 225 \mathrm{mM}$ (Promega), $1.5 \mu \mathrm{L}$ of $5 \times$ buffer (Promega), $0.5 \mu \mathrm{L}$ of DMSO $0.08 \mathrm{mM}$, $0.5 \mu \mathrm{L}$ of dNTPs $10 \mathrm{mM}$ (Promega), $5 \mathrm{U}$ of GoTaq G2 DNA Polymerase (Promega) and $3 \mu \mathrm{L}$ of total DNA. PCR temperature conditions were $94^{\circ} \mathrm{C}$ for $3 \mathrm{~min}$ (initial denaturation), followed by 35 cycles at $94^{\circ} \mathrm{C}$ for $45 \mathrm{~s}$ (denaturation), $58^{\circ} \mathrm{C}$ for $40 \mathrm{~s}$ (annealing), $72^{\circ} \mathrm{C}$ for $1 \mathrm{~min}$ (extension) and a final post-amplification at $72^{\circ} \mathrm{C}$ for $10 \mathrm{~min}$ (Mattiucci et al., 2016).

\subsection{Statistical analysis of the genetic data}

Analysis of spatial genetic structure of $A$. simplex (s. s.) samples from the herring subpopulations studied was carried out through a hierarchical AMOVA, which is based on partitioning of variance components attributable to population variance and to individuals within the populations. Significance of pairwise population comparison was tested with 1023 permutations.

Pairwise genetic differentiation of A. simplex (s. s.) among herrings of different fishing grounds was estimated using $F_{s t}$. This last parameter ranges from a maximum value of $F_{s t}=1$ - indicating complete differentiation among sequences of pre-defined populations of the same species - to a value equal to $F_{s t}=0$, which indicates no differentiation

Table 1

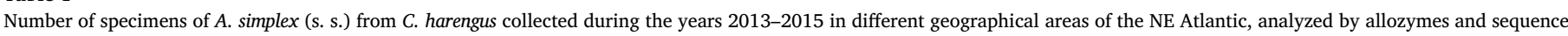
analysis of mtDNA cox2 and EF1 $\alpha-1$ nDNA genes.

\begin{tabular}{|c|c|c|c|c|c|}
\hline \multirow[t]{2}{*}{ Sampling area } & $\mathrm{N}$ & $\mathrm{N}$ & $\mathrm{N}$ & $\mathrm{N}$ & $\mathrm{N}$ \\
\hline & C. harengus & A. simplex (s. s.) & allozyme & mtDNA $\operatorname{cox} 2$ & $\mathrm{EF} 1 \alpha-1 \mathrm{nDNA}$ \\
\hline 1. Norwegian Sea (NWS) $64^{\circ} 41^{\prime} \mathrm{N} 00^{\circ} 47^{\prime} \mathrm{E}$ & 90 & 228 & 228 & 228 & 40 \\
\hline 2. North Sea (NOS) $54^{\circ} 42^{\prime} \mathrm{N} 0^{\circ} 44^{\prime} \mathrm{E}$ & 45 & 129 & 129 & 129 & 40 \\
\hline 3. English Channel (ECH) $50^{\circ} 26^{\prime} \mathrm{N} 1^{\circ} 19^{\prime} \mathrm{E}$ & 80 & 181 & 181 & 181 & 40 \\
\hline 4. Baltic Sea (BTS) $54^{\circ} 24^{\prime} \mathrm{N} 13^{\circ} 42^{\prime} \mathrm{E}$ & 50 & 116 & 116 & 116 & 40 \\
\hline
\end{tabular}


Table 2

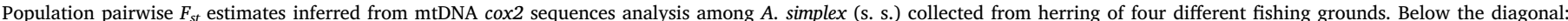
conventional $\mathrm{F}_{s t}$ from haplotype frequencies; Above the diagonal: $P$ values of $\mathrm{F}_{\mathrm{st}}$; significance level $0.05, *=$ significant value.

\begin{tabular}{|c|c|c|c|c|}
\hline A. simplex (s. s.) & NWS & NOS & $\mathrm{ECH}$ & BS \\
\hline 1. Norwegian Sea (NWS) & - & $0.0000 \pm 0.0000^{*}$ & $0.0019 \pm 0.0014^{*}$ & $0.001 \pm 0.0010^{*}$ \\
\hline 2. North Sea (NOS) & 0.0051 & - & $0.1728 \pm 0.0101$ & $0.7041 \pm 0.0158$ \\
\hline 3. English Channel (ECH) & 0.0057 & 0.0009 & - & $0.1953 \pm 0.0141$ \\
\hline 4. Baltic Sea (BTS) & 0.0059 & 0.0010 & 0.0009 & - \\
\hline
\end{tabular}

among the populations. Pairwise comparisons of $F_{s t}$ at the $P \leq 0.05$ level were based on 1000 permutations of the data matrix. AMOVA and $F_{s t}$ were calculated using the software Arlequin 3.5 (Excoffier and Lischer, 2010).

A null hypothesis of population panmixia was tested with an exact test of the differentiation of haplotypes among populations implemented in Arlequin 3.5 software. Two neutrality tests, Tajima's D (Tajima, 1989) and Fu's Fs (Fu, 1997), were calculated to verify the null hypothesis of selective neutrality, which would be expected with population expansion. Mismatch distribution (Harpending, 1994) was used for estimation of sudden population expansion or balance and tested in Arlequin 3.5. The fit between the observed and expected distributions was tested using the Harpending raggedness index (HRI) (Harpending, 1994) and the sum of squared deviations (SSD) for the estimated models of stepwise expansion (Schneider and Excoffier, 1999) in Arlequin 3.5. Statistical significance was estimated based on the parameters with 1000 permutation tests under the null hypothesis that sudden population expansion cannot be rejected.

Isolation By Distance (IBD) (Jensen et al., 2005) calculated using the Mantel test (with 1000 permutations of the matrices) was tested to evaluate a possible correlation between geographical distance of the parasite populations collected from those herring subpopulations, and the variation of $F_{s t}$ values.

Estimates of population genetic diversity of $A$. simplex (s. s.) among fishing grounds/sampling areas, as inferred from mtDNA cox2 sequence analysis, have been estimated at the following standard statistics parameters: number of haplotypes $(\mathrm{Nh})$, number of unique haplotypes $(N u h)$, nucleotide diversity $(\pi)$, haplotype diversity $(H d)$, average number of differences $(K)$, number of polymorphic sites $(S)$ to test deviation from selective neutrality model under demographic processes. All parameters were estimated using Arlequin 3.5 software (Excoffier and Lischer, 2010).

Haplotype network construction was carried out using the NETWORK 4.6 software (http://www.fluxus-engineering.com), based on mtDNA cox 2 sequences. It was performed by using Star Contraction as pre-processing calculation (Forster et al., 2001), the Median-Joining for the network calculation (Bandelt et al., 1999), and the Maximum Parsimony calculation, as the optional post-processing (Polzin and Daneschmand, 2003). Circle sizes are proportional to the corresponding haplotype frequencies.

\section{Results}

\subsection{Genetic identification of Anisakis spp. larvae}

All Anisakis spp. larvae $(\mathrm{N}=654)$ from Atlantic herring caught at four fishing grounds tin the NE Atlantic Ocean, were first assigned to Anisakis Type I larvae (sensu Berland, 1961). In accordance with the diagnostic alleles $A d k-2^{105}$, Pep $C-1^{90}$, Pep $C-2^{96}$ as indicated by Mattiucci et al. (2014b), all 654 larvae corresponded to species $A$. simplex (s. s.). The mtDNA cox 2 sequences showed $99 \%$ or $100 \%$ similarity with sequences of mtDNA cox 2 previously obtained for $A$. simplex (s. s.) (Mattiucci et al., 2014b), and retrievable from GenBank. Some of the mtDNA cox2 sequences obtained were deposited in GenBank under the accession numbers: KY595216-KY595227.

In addition, according to the diagnostic positions found at the EF1 $\alpha-1$ region of the nDNA (409 bp), i.e. showing a $\mathrm{C}$ and a $\mathrm{T}$ in $A$. simplex (s. s.), respectively, at position 186 and 286, the sample of larvae $(\mathrm{N}=160)$ (Table 1) were assigned to species A. simplex (s. s.). Some of the present sequences of EF1 $\alpha-1$ region of nDNA were deposited in GenBank under the accession numbers: KY613505-KY613510.

Therefore, concordant results were obtained for all markers, i.e. all larvae examined $(\mathrm{N}=654)$ were assigned to species $A$. simplex (s. s.).

\subsection{Population genetic structure of A. simplex (s. s.)}

Estimates of genetic differentiation between populations inferred from the fixation index $\left(F_{s t}\right)$ are shown in Table 2. A significant level of differentiation $\left(F_{s t}=0.0036, P=0.0000\right)$ was observed overall among the four populations of $A$. simplex (s. s.) from herring sampled in the North East Atlantic Ocean (Table 3). Significant genetic differentiation $F_{s t}$ was found between A. simplex (s. s.) from the Norwegian Sea and Baltic Sea herring populations $\left(F_{s t}=0.0059, P=0.001 \pm 0.0010\right)$, between the Norwegian Sea and North Sea populations $\left(F_{s t}=0.0051\right.$, $P=0.0000 \pm 0.0000$ ), and, finally, between populations of $A$. simplex (s. s.) sampled from the Norwegian Sea and English Channel $\left(F_{s t}=0.0057, P=0.0019 \pm 0.0014\right)$ (Table 2). A. simplex (s. s.) from the North Sea had a lower $F_{s t}$ and was not significantly different from larvae of the Baltic Sea $\left(F_{s t}=0.0010, P=0.7041 \pm 0.0158\right)$ and English Channel $\left(F_{s t}=0.0009, P=0.1728 \pm 0.0101\right)$. Additionally, the populations of $A$. simplex (s. s.) from the Baltic Sea and the English Channel were not significantly different from each other $\left(F_{s t}=0.0009\right.$; $P=0.1953 \pm 0.0141$, Table 2).

AMOVA analysis (Table 3 ) attributed $0.36 \%$ of the genetic variation among the A. simplex (s. s.) populations from the different geographical areas, and $99.64 \%$ of genetic variance within populations. In addition, the overall $F_{s t}$ value for $A$. simplex (s. s.) among the four sampling areas was $0.0036(P=0.0000)$ (Table 3$)$.

Isolation By Distance (IBD) analysis correlation between genetic and geographic distance matrices, calculated using Mantel Test (4 analysis using no log-trasformed and log-transformed data were run), did not provide statistically significant values ( $p$ value for the 4 analysis ranged

Table 3

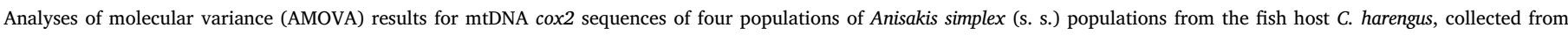
selected localities.

\begin{tabular}{|c|c|c|c|c|c|c|}
\hline Source of variation & Degrees of freedom & Sum of squares & Variance components & Percentage of variation & Overall $\left(\mathrm{F}_{s t}\right)$ & $P\left(\mathrm{~F}_{s t}\right)$ \\
\hline Among populations & 3 & 2.306 & 0.00177 & 0.36 & 0.0036 & 0.0000 \\
\hline Within populations & 650 & 316.512 & 0.48694 & 99.64 & & \\
\hline Total & 653 & 318.818 & 0.48871 & & & \\
\hline
\end{tabular}


Table 4

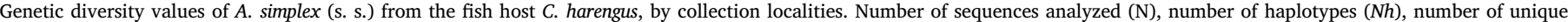

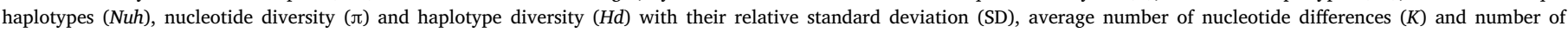
polymorphic sites $(S)$, are reported.

\begin{tabular}{|c|c|c|c|c|c|c|c|}
\hline & $\mathrm{N}$ & $N h$ & Nuh & $\pi \pm \mathrm{SD}$ & $H d \pm \mathrm{SD}$ & $K$ & $S$ \\
\hline 1. Norwegian Sea (NWS) & 228 & 145 & 106 & $0.007 \pm 0.004$ & $0.979 \pm 0.004$ & 4.048 & 81 \\
\hline 2. North Sea (NOS) & 129 & 93 & 60 & $0.007 \pm 0.004$ & $0.975 \pm 0.009$ & 3.955 & 65 \\
\hline 3. English Channel (ECH) & 181 & 122 & 87 & $0.008 \pm 0.004$ & $0.969 \pm 0.009$ & 4.461 & 94 \\
\hline 4. Baltic Sea (BTS) & 116 & 80 & 52 & $0.008 \pm 0.004$ & $0.969 \pm 0.010$ & 4.214 & 64 \\
\hline Total & 654 & 358 & - & $0.0075 \pm 0.0002$ & $0.976 \pm 0.003$ & 4.228 & 157 \\
\hline
\end{tabular}

between 0.543 and 0.632 ).

\subsection{Genetic diversity of A. simplex (s. s.) populations}

Based on mtDNA cox2 sequences analysis $(\mathrm{N}=654)$, A. simplex (s. s.) larvae exhibited 358 haplotypes (Table 4). Among the 157 polymorphic sites recorded, 70 were singleton variable sites (66 singleton variable sites with 2 variants), whereas 87 were parsimony informative. The sequences of $A$. simplex (s. s.) specimens showed high haplotype diversity (on average, $H d=0.976$ ) values, and low nucleotide diversity values (on average, $\pi=0.0075$ ) (Table 4 ). The average number of nucleotide differences was 4.228. Similar values of nucleotide diversity were observed in all four populations of A. simplex (s. s.) investigated (Table 4), with $\pi$ values ranging between 0.007 and 0.008 , despite the larger number of unique haplotypes from the Norwegian Sea population compared to the other populations (Table 4). On the other hand, haplotype diversity $(H d)$ ranged between a minimum value of 0.969 for the Baltic Sea sample, to a maximum value of 0.979 for the Norwegian Sea population of A. simplex (s. s.) (Table 4).

Tajima's D value resulted negative for all four fishing grounds, with a significant overall Tajima's $\mathrm{D}=-2.13869(P=0.001)$ (Table 5). Additionally, Fu's Fs value was negative for the four populations and, thus, the null hypothesis of a constant population size (i.e. the population evolves according to the infinite-site model and all mutations are selectively neutral) was rejected (Fu's $\mathrm{F}=-25.64927, P=0.00000$, on average) (Table 5). Inference on demographic history of A. simplex (s. s.) from the four herring populations from North East Atlantic fishing grounds, obtained by mismatch distribution analysis, exhibited a sudden population expansion, showing no deviation from a predicted model of sudden population expansion (see supplementary data in Appendix A).

A reconstructed median joining network (Fig. 2) shows the relationship among the 358 haplotypes observed in the 654 specimens of A. simplex (s. s.) sequenced at the mtDNA cox 2 from the present herring populations. Seven common haplotypes were shared by all four $A$. simplex (s. s.) populations (named $\mathrm{H} 1, \mathrm{H} 2, \mathrm{H} 3, \mathrm{H} 4, \mathrm{H} 5, \mathrm{H} 6, \mathrm{H} 7$ in Fig. 2), with a relative frequency ranging from a minimum value of $0.6 \%$ (H7), to a maximum of $13.3 \%$ (H1), when considering all 654 sequences analyzed (Fig. 2). Some of the seven common haplotypes observed showed different relative frequencies in different sampling areas. For example, H1 showed highest relative frequency among all

Table 5

Tajima's D and Fu's Fs statistics with corresponding $P$-values, based on mtDNA cox 2 gene sequences data of $A$. simplex (s. s.) from the herrings of the four fishing grounds examined. $P$-values of D; significance level 0.05. $P$-values of Fs; significance level 0.02 .

\begin{tabular}{llllll}
\hline & \multicolumn{3}{l}{ Tajima's D } & & \multicolumn{2}{l}{ Fu's Fs } \\
\cline { 2 - 3 } \cline { 5 - 6 } \cline { 5 - 6 } & $\mathrm{D}$ & $P$ & & Fs & $P$ \\
\hline Norwegian Sea (NWS) & -2.12352 & 0.00000 & & -25.54022 & 0.00000 \\
North Sea (NOS) & -2.10773 & 0.00100 & & -25.84373 & 0.00000 \\
English Channel (ECH) & -2.25997 & 0.00000 & & -25.45616 & 0.00000 \\
Baltic Sea (BTS) & -2.06355 & 0.00300 & & -25.75696 & 0.00000 \\
Mean value & -2.13869 & 0.00100 & & -25.64927 & 0.00000 \\
\hline
\end{tabular}

common haplotypes observed. It occurred in herring from all four geographical areas, with a frequency reported as follow: in 19 A. simplex (s. s.) specimens (16.4\%) collected from herring in the Baltic Sea, 19 (14.7\%) specimens from the North Sea, 30 specimens (16.6\%) from the English Channel, and 19 larvae (8.83\%) from the Norwegian Sea. The shared haplotype $\mathrm{H} 2$ showed high relative frequency in $A$. simplex from herring in the Norwegian Sea (7.9\%) and English Channel (5.5\%), whereas there was only very low $\mathrm{H} 2$ frequency in the parasite samples from herring caught in the Baltic Sea $(0.9 \%)$ and North Sea $(0.8 \%)$ areas (represented by just one specimen in each sampling locality) (Fig. 2). Finally, H3 common haplotype occurred with low frequency in the Norwegian Sea and English Channel, i.e. 0.9\% and 0.6\%, respectively, however, showing higher frequencies in the North Sea $(3.9 \%)$ and Baltic Sea (2.6\%).

Interestingly, A. simplex (s. s.) larvae $(\mathrm{N}=228)$ sampled in Norwegian Sea showed 106 unique haplotypes, among the 145 haplotypes observed in this area; the remaining haplotypes from this particular A. simplex (s. s.) population were shared with the English Channel (26 haplotypes), the North Sea (24 haplotypes) and the Baltic Sea (18 haplotypes) samples (Fig. 3). On the contrary, the lowest number of unique haplotypes (Nhu =52, Table 4 and Fig. 3) was observed for larvae obtained from Baltic Sea herring (Table 4 and Fig. 3). Finally, specimens sampled in the North Sea showed 60 unique haplotypes; whereas 87 unique haplotypes were recorded in the A. simplex (s. s.) population from herring caught in the English Channel (Table 4 and Fig. 3).

\section{Discussion}

A total of 654 A. simplex (s. s.) larvae were identified using a multilocus genetic approach (diagnostic allozymes, EF1 $\alpha-1$ nDNA and the mtDNA cox2 sequences analysis). The parasite specimens were obtained from herring caught at four fishing grounds in the NE Atlantic Ocean, corresponding to four putative herring stocks. Population genetic differentiation of A. simplex (s. s.) from these four herring stocks was estimated intraspecifically by mtDNA cox 2 sequence analysis. Spatial comparison based on molecular variance analysis and $F_{s t}$ values (among regions) performed for the collected specimens of $A$. simplex (s. s.), revealed a certain level of genetic sub-structuring between some of the present herring (overall Fst $=0.0036, P=0.0000$ ).

The population structure of $A$. simplex (s. s.) inferred from mtDNA cox2 sequence analysis seems to follow the suggested herring stock structure throughout the NE Atlantic area. Especially the A. simplex (s. s.) population from herring fished in the Norwegian Sea (NWS; $64^{\circ} 41^{\prime} \mathrm{N}$ $00^{\circ} 47^{\prime}$ E, Fig. 1) could be related to the Norwegian Sea herring stock (NSS) (Fig. 1). At the same time, the parasite populations from herring of the Baltic Sea (BTS; $54^{\circ} 24^{\prime} \mathrm{N} 13^{\circ} 42^{\prime} \mathrm{E}$ ) and the North Sea (NOS; $54^{\circ} 42^{\prime} \mathrm{N} 0^{\circ} 44^{\prime} \mathrm{E}$ ) appear to be related to the western Baltic spring spawning (WBSS) and to the North Sea autumn spawning (NSAS) herring stocks, respectively. On the other hand, the A. simplex (s. s.) population from herring fished along the English Channel coast (named $\mathrm{ECH} ; 50^{\circ} 26^{\prime} \mathrm{N} 1^{\circ} 19^{\prime} \mathrm{E}$ ) could be in accordance with the existence of the English Channel winter spawning Downs of C. harengus (Mariani et al., 2005; ICES, 2016a). The latter represents the southernmost herring 


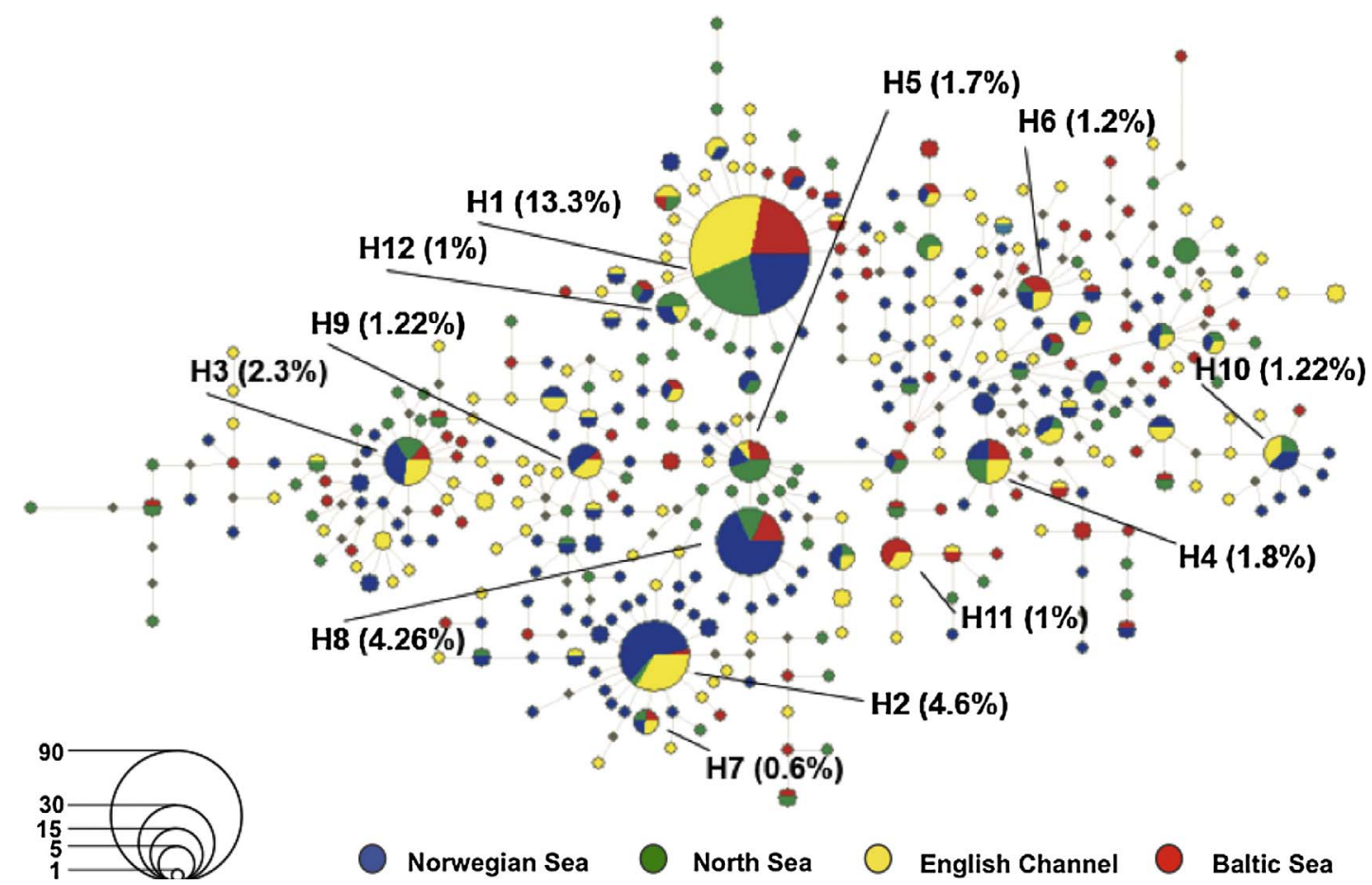

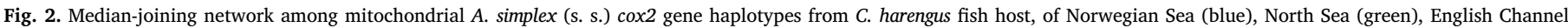

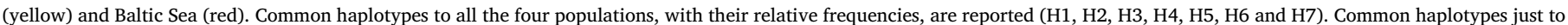

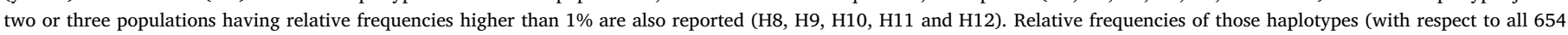

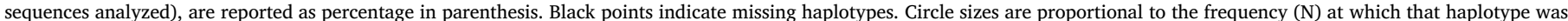
observed in the data set.

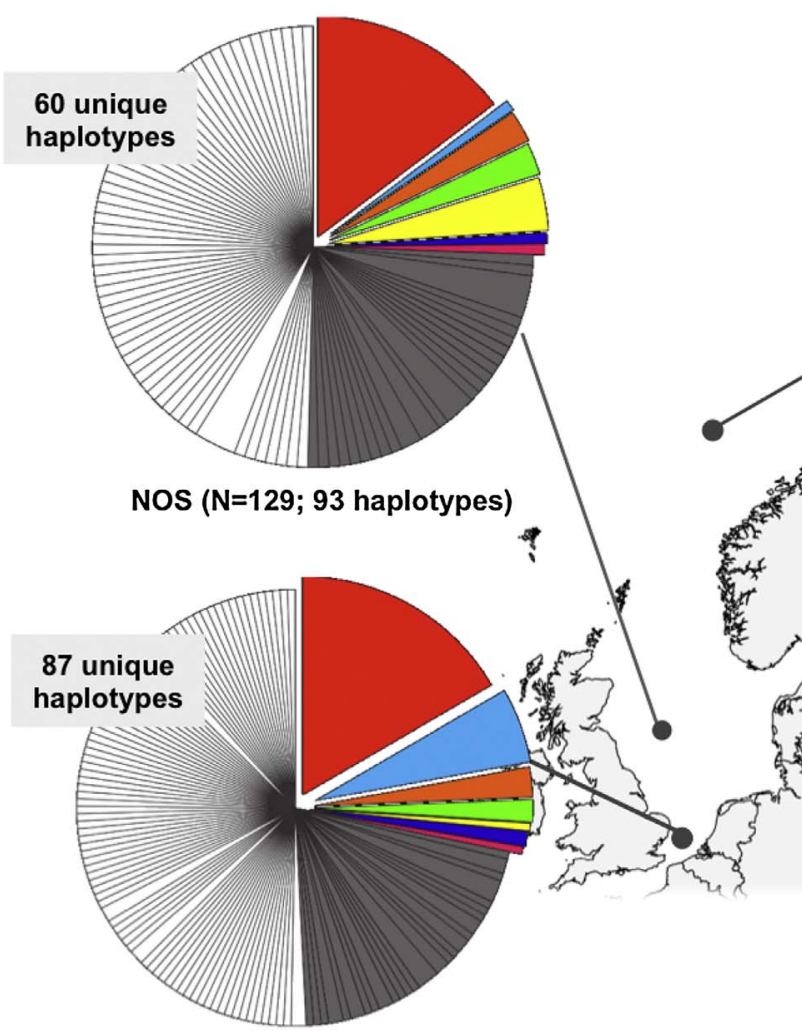

ECH (N=181; 122 haplotypes)

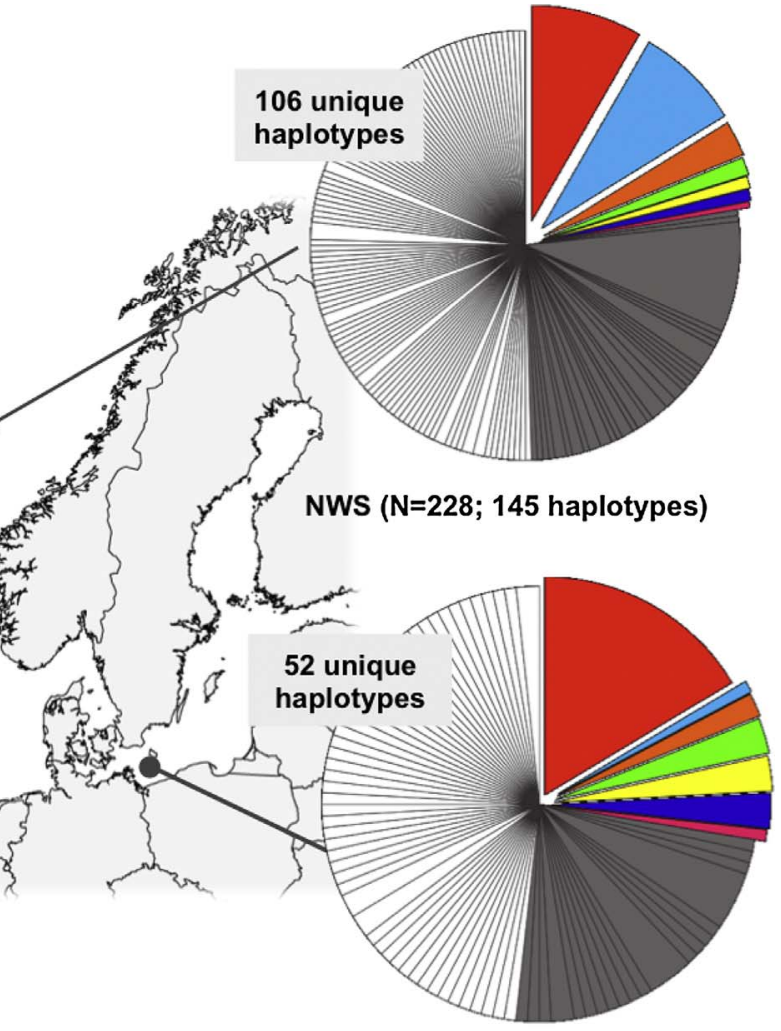

BTS ( $N=116 ; 80$ haplotypes)

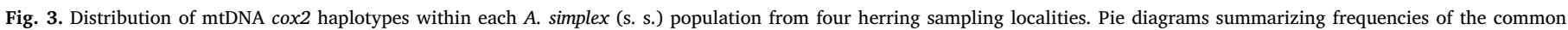

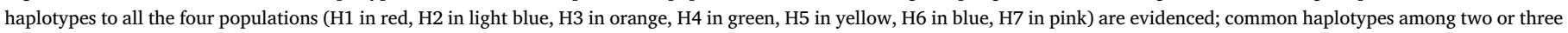
populations are reported in grey; unique haplotypes Nuh specifically found at each population are shown in white color. 
population of the North Sea stock including the North Sea autumn spawning stock component (NSAS) (Mariani et al., 2005; ICES, 2016a).

The high mobility of intermediate/paratenic and definitive hosts involved in the life-cycle of $A$. simplex (s. s.) in the North Atlantic Ocean surely represents a source of gene flow between populations of the parasite species at both nuclear (allozymes) (Mattiucci and Nascetti, 2008) and mitochondrial (mtDNA cox2) level (Baldwin et al., 2011; Klapper et al., 2016). Therefore, the likelihood for a high gene flow value between populations of $A$. simplex (s. s.) (Mattiucci and Nascetti, 2008) obtained from herrings, may be a result of the high vagility of definitve hosts involved in the life-cycle of the parasite species from those sampling areas. On the other hand, IBD analysis correlation between genetic and geographic distance matrices in the parasite populations studied did not show a statistically significant value. This finding seems to be in accordance with the fact that the A. simplex (s. s.) subpopulations from those herring samples cannot be considered as distant from a geographical point of view. The slight genetic differentiation (Fst value) found between the A. simplex (s. s.) populations is likely a result of the herring's stocks movements and subpopulation structuring in those fishing grounds, rather than to the physical geographic distance between their nematode parasites populations. On the other hand, the population structure of definitive and intermediate/ paratenic hosts could also play a role in shaping the differences in genetic structure at parasite species level. Indeed, the population structure of Anisakis simplex (s. s.) could be closely tied to the migratory pattern of herring, but also to the highly migratory capacity of its definitive hosts, represented by different cetacean species which frequently occur in the studied areas. Several species of large migratory cetaceans such as the minke whale Balenoptera acutorostrata, humpback whale Megaptera novaeangliae, and killer whale Orcinus orca, inhabit the open waters of the Norwegian Sea (Leatherwood and Reeves, 1983), whereas smaller and more resident dolphin populations of bottlenose dolphins Tursiops truncatus inhabiting the central North Sea, whose probably contribute to maintain the A. simplex (s. s.) life cycle in the area. Minke whales is distributed in the northern hemisphere from the Atlantic coast of France to Greenland (Leatherwood and Reeves, 1983), and are reported as suitable hosts for A. simplex (s. s.) (Mattiucci and Nascetti, 2008; Mattiucci et al., 2014b). However, although this species is a highly migratory cetacean, it rarely migrates from the northern Norwegian Sea into the Baltic Sea, where, instead, much more resident dolphin species, such as Phocoena phocoena, inhabit coastal areas.

With regards to the fish intermediate/paratenic host of $A$. simplex (s. s.), Atlantic herring performs extensive seasonal migrations between spawning, feeding, and wintering areas, and different stock components often intermix at the feeding and wintering grounds (Rosenberg and Palmén, 1981; Wheeler and Winters, 1984; Husebø et al., 2005; Ruzzante et al., 2006; Reiss et al., 2009; ICES, 2016a). Furthermore, $C$. harengus population dynamics are complex, and different stocks often display variation in life history and spawning season (Jennings and Beverton, 1991; McQuinn, 1997), as evidenced by the differences observed in their population genetic structuring (Bekkevold et al., 2005; Mariani et al., 2005). Norwegian spring spawning herring stock (NSS) seems to migrate over large areas in the North East Atlantic, but it remains along the Norwegian continental shelf; it may not migrate to Skagerrat, the basin water that connects the North Atlantic to the Baltic Sea (Dragesund et al., 1997; Slotte and Johannessen, 1997; Kvamme et al., 2003; Husebø et al., 2005). The herring larvae drift northward with the Norwegian coastal current, up to the Barents Sea and northern Norwegian Fjords (Shaw et al., 1999; Hay et al., 2000). They remain in the nursery area until spring; in their third year before moving southwards along the Norwegian coast where they feed and intermix with older age groups, and at the age of 5-8 they mature and spawn (Shaw et al., 1999; Hay et al., 2000).

Thus, the slight but significant level of differentiation found between the A. simplex (s. s.) samples of the Norwegian Sea and Baltic Sea could be related to the different distributions of both main definitive host species (such as B. acutorostrata) and the Norwegian and Baltic herring stocks.

On the contrary, the $F_{s t}$ values found among the populations of $A$. simplex (s. s.) from herring fished in the North Sea, the English Channel, and the Baltic Sea, revealed a lower degree differentiation between these populations. This findings could be explained by the herring populations/stocks features in that area of the Atlantic Ocean, characterized by a long temporal persistence of the three different herring stocks in the same area of feeding.

Generally, the North Sea autumn spawning stock (NSAS) spawns in the western part of the North Sea on late summer and autumn (Hay et al., 2000). Studies on tagging and morphometric character differences showed that larvae drift east across the North Sea and into the Skagerrak, Kattegat, and inner Danish waters, where they feed for one to three years before returning during spring to spawning locations in the western North Sea (Iles and Sinclair, 1982; Bekkevold et al., 2005).The herring population belonging to the English Channel winter spawning Downs generally seems to follow the same migration pattern of the North Sea autumn spawning herring stock (NSAS) (Corten, 2013). On the other hand, the Western Baltic spring spawning stock (WBSS) migrates in early spring to feeding areas in the Kattegat, Skagerrak and in the Eastern North Sea (Division IIIa) (ICES, 2016b). As a result, Division IIIa is defined as an area of mixed feeding both of juvenile North Sea autumn spawning (NSAS), English Channel winter spawning Downs and adult Spring Baltic spawners (Ruzzante et al,, 2006; Bekkevold et al., 2005). All these three populations of $C$. harengus are feeding in this area on the same zooplankton organisms, which are likely infected with A. simplex (s. s.) larvae. In turn, this feeding area/ period of herring represents a prey spot area for different predatory cetacean species such as harbor porpoise $P$. phocoena, minke whale $B$. acutorostrata, long-finned pilot whale Globicephala melas, white-beaked dolphin Lagenorhynchus albirostris and bottlenose dolphin Tursiops truncatus, whose diet includes herring (Reid et al., 2003). This ecological dynamic, and the presence of suitable hosts at different trophic levels, could be responsible to maintain the life-cycle of $A$. simplex (s. s.) in this area.

Interestingly, the weak genetic differentiation between the North Sea and English Channel populations of $A$. simplex (s. s.) $\left(F_{s t}=0.0009\right.$, $P=0.1728 \pm 0.0101)$ was in agreement with data obtained by DNA microsatellite analysis carried out on the fish host, suggesting the existence of low level of genetic differentiation between the two corresponding herring stocks, i.e. the North Sea autumn spawning stock (NSAS) and the English Channel winter spawning Downs (Mariani et al., 2005).

The genetic diversity of the A. simplex (s. s.) samples from four different sampling areas, estimated by numbers of haplotypes $(\mathrm{Nh})$, nucleotide diversity $(\pi)$, haplotype diversity $(H d)$, number of polymorphic sites (S) and average number of differences (K) obtained at the mtDNA cox2 locus, was similar to those recorded in other populations of A. simplex (s. s.) from the North Atlantic Ocean (Baldwin et al., 2011; Klapper et al., 2016).

All four A. simplex (s. s.) populations examined shared seven common haplotypes, namely H1, H2, H3, H4, H5, H6, H7 (Fig. 2). Some of these haplotypes have been previously recorded by Klapper et al. (2016) in three A. simplex (s. s.) samples from beaked redfish Sebastes mentella from East Greenland, Tampen (northern North Sea) and Bear Island (Barents Sea). In particular, the most common haplotype (here named H1) corresponds to the same most frequently occurring haplotype shared by all three populations recorded by Klapper et al. (2016) (who named it H5). The same H1 haplotype appears to be the most common in A. simplex (s. s.) throughout its geographical range (Mattiucci pers. comm.); it likely corresponds to the most ancestral haplotype of the parasite species. Furthermore, one haplotype shared between Tampen and Greenland (H13) in Klapper et al. (2016) was also recorded in the present study under the name $\mathrm{H} 3$, and thus ranks among the most common haplotypes in all four analyzed populations. 
Finally, despite the large geographical distance between the present $A$. simplex (s. s.) samples and those analyzed by Klapper et al. (2016), some other haplotypes are shared as well, and are present in all populations of A. simplex (s. s.) in the NE Atlantic Ocean.

The number of unique haplotypes $(N u h=106)$ found in the Norwegian Sea population of $A$. simplex (s. s.) was higher than in the other populations (North Sea Nuh $=60$, English Channel $N u h=87$, Baltic Sea Nuh =52). This finding could be related to higher abundance of the parasite in this particular area of the North East Atlantic. Moreover, high infection levels by A. simplex (s. s.) in minke whale have been recorded in stranded specimens in this area, as well (Ugland et al., 2004; Mattiucci, pers. comm.). The high density of parasites in a particular area could be the result of high demography, in the trophic web, of the definitive and intermediate/paratenic hosts involved in the parasite life cycle (Mattiucci and Nascetti, 2008). Furthermore, it has been suggested that the distribution of the genetic variability of anisakid nematode populations reflects their demography, thus reflecting a large effective parasite population size, availability and population size of their hosts, and the stability of marine trophic webs (Mattiucci and Nascetti, 2008). Finally, both Tajima's D and Fu's F tests resulted highly negative, showing that the rejection of a neutral evolution null hypothesis for A. simplex (s. s.) populations was confirmed, whereas mismatch distribution analysis showed that populations examined could have been subjected to a sudden demographic expansion. Mismatch distribution analysis on the A. simplex (s. s.) species from $C$. harengus North East Atlantic populations shown a not significant difference between observed and expected trend of demographic population growth.

\section{Conclusions}

As previously reported in Criscione et al. (2006), Baldwin (2011), Mattiucci et al. (2014a) and Klapper et al. (2016), mitochondrial DNA genes, due to the faster accumulation of base pairs substitution and maternal inheritance, have proven to be suitable genetic markers to infer population structure in parasite species. The population structure of A. simplex (s. s.) from C. harengus of the NE Atlantic waters, inferred by mtDNA $\operatorname{cox} 2$ sequences analysis, suggest the presence of a certain level of genetic sub-structuring of this parasite throughout this oceanic basin water.

The revealed spatial population structure of $A$. simplex (s. s.) seems to mirror the herring population structure, as previously suggested for this fish species (ICES, 2007, 2016a, 2016b) in fishing grounds of NE Atlantic. This finding suggests that the genetic structuring of a parasite species could be used, in a multidisciplinary approach, as a marker of its fish stocks throughout a geographical area.

Finally, the study of A. simplex (s. s.) population genetic structure and its phylogeography could be useful in future co-phylogeographical analyses, allowing to gain more insight about the genetic structure of their intermediate/paratenic and definitive hosts.

\section{Acknowledgements}

The research was carried out with funding received from the European Union's Seventh Framework Programme for research, technological development and demonstration, under the grant agreement no. 312068 "PARASITE". The authors are grateful to two anonymous referees whose comments helped to improve the MS.

\section{Appendix A. Supplementary data}

Supplementary data associated with this article can be found, in the online version, at http://dx.doi.org/10.1016/j.fishres.2017.08.002.

\section{References}

Anderson, R.C., 2000. Nematode Parasites of Vertebrates: Their Development and Transmission. CAB International, Wallingford, UK.

André, C., Larsson, L.C., Laikre, L., Bekkevold, D., Brigham, J., Carvalho, G.R., Dahlgren, T.G., Hutchinson, W.F., Mariani, S., Mudde, K., Ruzzante, D.E., Ryman, N., 2011. Detecting population structure in a high gene-flow species, Atlantic herring (Clupea harengus): direct, simultaneous evaluation of neutral vs putatively selected loci. Heredity 106, 270-280.

Baldwin, R.E., Rew, M.B., Johansson, M.L., Banks, M.A., Jacobson, K.C., 2011. Population structure of three species of Anisakis nematodes recovered from Pacific Sardines (Sardinops sagax) distributed throughout the California Current System. J. Parasitol. 97, 545-554.

Bandelt, H.J., Forster, P., Röhl, A., 1999. Median-joining networks for inferring intraspecific phylogenies. Mol. Biol. Evol. 16, 37-48.

Bekkevold, D., André, C., Dahlgren, T.G., Clausen, L.A.W., Torsetensen, W., Mosegaard, H., Carvalho, G.R., Christensen, T.B., Norlinder, E., Ruzzante, D.E., 2005. Enviromental correlates of population differentiation in atlantic Herring. Evolution $59,2656-2668$.

Beverley-Burton, M., Pippy, J.H.C., 1977. Morphometric variations among larval Anisakis simplex (Nematoda: Ascaridoidea) from fishes of the North Atlantic and their use as biological indicators of host stocks. Environ. Biol. Fish. 2, 309-314.

Bierman, S.M., Dickey-Collas, M., Van Damme, C.J.G., Van Overzee, H.M.J., PennockVos, M.G., Tribuhl, S.V., Clausen, L.A.W., 2010. Between-year variability in the mixing of North Sea herring spawning components leads to pronounced variation in the composition of the catch. ICES J. Mar. Sci. 67, 885-896.

Brophy, D., Danilowicz, B.S., 2002. Tracing populations of Atlantic herring (Clupea harengus L.) in the Irish and Celtic Seas using otolith microstructure. ICES J. Mar. Sci. 59, 1305-1313.

Chenoweth, J.F., McGladdery, S.E., Sindermann, C.J., Sawyer, T.K., Bier, J.W., 1986. An investigation into the usefulness of parasites as tags for herring (Clupea harengus) stocks in the western North Atlantic, with emphasis on use of the larval nematode Anisakis simplex. J. Northwest Atl. Fish. Sci. 7, 25-33.

Clausen, L.A.W., Bekkevold, D., Hatfield, E.M.C., Mosegaard, H., 2007. Application and validation of otolith microstructure as a stock identification method in mixed Atlantic herring (Clupea harengus) stocks in the North Sea and western Baltic. ICES J. Mar. Sci J.Cons. 64, 377-385.

Corten, A., 2013. Recruitment depressions in north sea herring. ICES J. Mar. Sci. 70, 1-15.

Criscione, C.D., Poulin, R., Blouin, M.S., 2005. Molecular ecology of parasites: elucidating ecological and microevolutionary processes. Mol. Ecol. 14, 2247-2257.

Criscione, C.D., Cooper, B., Blouin, M.S., 2006. Parasite genotypes identify source populations of migratory fish more accurately than fish genotypes. Ecology 87, 823-828.

Cross, M.A., Collins, C., Campbell, N., Watts, P.C., Chubb, J.C., Cunningham, C.O., Hatfield, E.M.C., MacKenzie, K., 2007. Levels of intra-host and temporal sequence variation in a large CO1 subunit from Anisakis simplex sensu stricto (Rudolphi, 1809) (Nematoda: Anisakidae): implications for fisheries managements. Mol. Biol. 151, 695-702.

Dickey-Collas, M., Nash, R.D.M., Brunel, T., Van Damme, C.J.G., Marshall, C.T., Payne, M.R., Corten, A., Geffen, A.J., Peck, M.A., Hatfield, E.M.C., Hintzen, N.T., Enberg, K., Kell, L.T., Simmonds, E.J., 2010. Lessons learned from stock collapse and recovery of North Sea herring: a review. ICES J. Mar. Sci. 67, 1875-1886.

Dragesund, O., Johannesen, A., Ulltang, Ø., 1997. Variation in migration and abundance of Norwegian spring spawning herring (Clupea harengus L.). Sarsia 82, 97-105.

Excoffier, L., Lischer, H.E.L., 2010. Arlequin suite ver 3.5: a new series of programs to perform population genetics analyses under Linux and Windows. Mol. Ecol. Res. 10, $564-567$.

FEAS, 2015. The stock book. Report to the Minister for Agriculture, Food and the Marine Annual Review of Fish Stocks in 2015 with Management Advice for 2016.

Forster, P., Torroni, A., Renfrew, C., Röhl, A., 2001. Phylogenetic star contraction applied to Asian and Papuan mtDNA evolution. Mol. Biol. Evol. 18, 1864-1881.

Froeschke, G., Von der Heyden, S., 2014. A review of molecular approaches for investigating patterns of coevolution in marine host-parasite relationships. Adv. Parasitol. 84, 231-234.

Fu, Y.X., 1997. Statistical tests of neutrality of mutations against population growth, hitchhiking and backgroud selection. Genetics 147, 915-925.

Geffen, A.J., Nash, R.D.M., Dickey-Collas, M., 2011. Characterization of herring populations west of the British Isles: an investigation of mixing based on otolith micro chemistry. ICES J. Mar. Sci. 68, 1447-1458.

Grohsler, T., Oeberst, R., Schaber, M., Larson, N., Kornilovs, G., 2013. Discrimination of western Baltic spring-spawning and central Baltic herring (Clupea harengus L.) based on growth vs. natural tag information. ICES J. Mar. Sci. 70, 1108-1117.

Harpending, R.C., 1994. Signature of ancient population growth in a low-resolution mitochondrial DNA mismatch distribution. Hum. Biol. 66, 591-600.

Hatfield, E.M.C., Zuur, A.F., Boyd, J., Campbell, N., Chubb, J.C., Collins, C.M., Coughlan, J., Cross, M.A., Cross, T.F., Cunningha, C.O., Geffen, A.J., MacKenzie, K., Nash, R.D.M., Jansen, S., Kay, S.M., Kelly, C.J., O'Leary, D.B., Schlickeisen, J., Schön, P.J., Watts, P.C., Zimmermann, C., 2005. WESTHER: a multidisciplinary approach to the identification of herring (Clupea harengus L.) stock components west of the British Isles using biological tags and genetic markers. ICES CM 01 (K).

Hauser, L., Turan, C., Carvalho, G.R., 2001. Haplotype frequency distribution and discriminatory power of two mtDNA fragments in a marine pelagic teleost (Atlantic herring, Clupea harengus). Heredity 87, 621-630.

Hay, D.E., Toresen, R., Stephenson, R., Thompson, M., Claytor, R., Funk, F., Ivshina, E., Jakobsson, J., Kobayashi, T., McQuinn, I., Melvin, G., Molloy, J., Naumenko, N., Oda, 
K.T., Parmanne, R., Power, M., Radchenko, V., Schweigert, J., Simmonds, J., Sjöstrand, B., Stevenson, D.K., Tanasichuk, R., Tang, Q., Watters, D.L., Wheeler, J., 2000. Taking stock: an inventory and review of world herring stocks in 2000 , in: herring: expectations for a new millennium, university of alaska sea grant college program, AK-SG-01-04. Fairbanks 1-21.

Herdson, D., Priede, I., 2010. Clupea Harengus. The IUCN Red List of Threatened Species 2010 (ver. 2010.4). (http://www.iucnredlist.org (Accessed 27 October 2010).

Huse, G., 2015. A spatial approach to understanding herring population dynamics. Can. J. Fish. Aquatic. Sci. 73, 177-188.

Husebø, A., Slotte, A., Clausen, L.A.W., Mosegaard, H., 2005. Mixing of populations or year class twinning in Norwegian spring spawning herring? Mar. Freshw. Res. 56, $763-772$.

ICES, 2006. Report of the ICES advisory committee on fishery management, advisory committee on the marine environment and advisory committee on ecosystems. ICES Adv. 1488, 1-10.

ICES, 2007. Report of the ICES advisory committee on fishery management, advisory committee on the marine environment and advisory committee on ecosystems. ICES Adv. 1333, 1-10.

ICES, 2016a. Report of herring assessment working group for the area south of 62(N (HAWG). Stock Annex: Herring (Clupea harengus) in Subarea 4 and Divisions 3. A and 7. d, Autumn Spawners (North Sea, Skagerrak and Katte-gat, Eastern English Channel). pp. 1-63.

ICES, 2016b. Report of herring assessment working group for the area south of 62(N (HAWG). Stock Annex: Herring (Clupea Harengus) in Subdivisions 20-24, Spring Spawners (Skagerrak, Kattegat, and Western Baltic). pp. 1-19.

ICES, 2016c. Report of working group on widely distributed stocks. Stock Annex: Herring (Clupea Harengus) in Subareas 1, 2, and 5, and in Divisions 4. a and 14. a (Norwegian Spring Spawning). pp. 1-56.

Iles, T.D., Sinclair, M., 1982. Atlantic herring stock discreteness and abundance. Science 215, 627-632.

Jørgensen, H.B.H., Hansen, M.M., Bekkevold, D., Ruzzante, D.E., Loeschcke, V., 2005. Marine landscapes and population genetic structure of herring (Clupea harengus L.) in the Baltic Sea. Mol. Ecol. 14, 3219-3234.

Jennings, S., Beverton, R.J.H., 1991. Intraspecific variation in the life history tactics of Atlantic herring (Clupea harengus L.). ICES J. Mar. Sci. 48, 117-125.

Jensen, J.L., Bohonak, A.J., Kelley, S.T., 2005. Isolation by distance, web service. BMC Genet. 6, 13.

Karl, H., Levsen, A., 2011. Occurrence and distribution of anisakid nematodes in Grey gurnard (Eutrigla gurnardus L.) from the North Sea. Food Control 22, 1634-1638.

Klapper, R., Kochmann, J., O'Hara, R.B., Karl, H., Kuhn, T., 2016. Parasites as biological tags for stock discrimination of beaked redfish (Sebastes mentella): parasite infracommunities vs limited resolution of cytochrome markers. Plos One 11, 4.

Klimpel, S., Palm, H.W., Rückert, S., Piatkowski, U., 2004. The life cycle of Anisakis simplex in the Norwegian Deep (northern North Sea). Parasitol. Res. 94, 1-9.

Kvamme, C., Noettestad, L., Fernø, A., Misund, O.A., Dommasnes, A., Axelsen, B.E., Dalpadado, P., Webjørn, M., 2003. Migration patterns in Norwegian spring-spawning herring: why young fish swim away from the wintering area in late summer. Mar. Ecol. Progr. Ser. 247, 197-210.

Leatherwood, S., Reeves, R., 1983. The Sierra Club Handbook of Whales and Dolphins.

Levsen, A., Svanevik, C.S., Cipriani, P., Mattiucci, S., Gay, M., Hastie, L.C., Pierce, G.J., Bušelić, I., Mladineo, I., Karl, H., Ostermeyer, U., Buchmann, K., Højgaard, D.P., González, A.F., Pascual, S., 2017. A survey of zoonotic nematodes of commercial key fish species from major European fishing grounds - introducing the EU FP7 PARASITE exposure assessment study. Fish. Res this issue.

Levsen, A., Lunestad, B.T., 2010. Anisakis simplex third stage larvae in Norwegian spring spawning herring (Clupea harengus L.), with emphasis on larval distribution in the flesh. Vet. Parasitol. 171, 247-253.

Limborg, M., Helyar, S.J., de Bruyn, M., Taylor, M.I., Nielsen, E.E., Ogden, R., Carvalho, G.R., Consortium, F.P.T., Bekkevold, D., 2012. Environmental selection on transcriptome-de-rived SNPs in a high gene flow marine fish, the Atlantic herring (Clupea harengus). Mol. Ecol. 21, 3686-3703.

Münster, J., Klimpel, S., Fock, H.O., MacKenzie, K., Kuhn, T., 2015. Parasites as biological tags to track an ontogenetic shift in the feeding behaviour of Gadus morhua off West and East Greenland. Parasitol. Res. 12, 2723-2733.

MacKenzie, K., Hemmingsen, W., 2005. Parasites as biological tags in marine fisheries research: European Atlantic waters. Parasitology 142, 54-67.

MacKenzie, K., 2002. Parasites as biological tags in population studies of marine organisms: an update. Parasitology 124, 153-163.

Mariani, S., Hutchinson, W.F., Hatfield, E.M.C., Ruzzante, D.E., Simmonds, E.J., Dahlgren, T.G., Andre, C., Brigham, J., Torstensen, E., Carvalho, G.R., 2005. North
Sea herring population structure revealed by microsatellite analysis. Mar. Ecol. Prog. Ser. 303, 245-257.

Mattiucci, S., Nascetti, G., 2008. Advances and trends in the molecular systematics of anisakid nematodes: with implications for their evolutionary ecology and hostparasite co-evolutionary processes. Adv. Parasitol. 66, 47-148.

Mattiucci, S., Cimmaruta, R., Cipriani, P., Abaunza, P., Bellisario, B., Nascetti, G., 2014a. Integrating Anisakis spp. parasites data and host genetic structure in the frame of a holistic approach for stock identification of selected Mediterranean Sea fish species. Parasitology 142, 90-108.

Mattiucci, S., Cipriani, P., Webb, S.C., Paoletti, M., Marcer, F., Bellisario, B., Gibson, D.I., Nascetti, G., 2014b. Genetic and morphological approaches distinguish the three sibling species of the Anisakis simplex species complex, with a species designation as Anisakis berlandi n. sp for A. simplex sp. C (Nematoda: Anisakidae). J. Parasitol. 100, 199-214.

Mattiucci, S., Acerra, V., Paoletti, M., Cipriani, P., Levsen, A., Webb, S.C., Canestrelli, D., Nascetti, G., 2016. No more time to stay 'single' in the detection of Anisakis pegreffii, A. simplex (s. s.) and hybridization events between them: a multi-marker nuclear genotyping approach. Parasitology 143, 998-1011.

Mattiucci, S., Cipriani, P., Paoletti, M., Levsen, A., Nascetti, G., 2017. Reviewing biodiversity and epidemiological aspects of anisakid nematodes from the North-East Atlantic Ocean. J. Helminthol. 91, 422-439.

McQuinn, I.H., 1997. Metapopulations and the Atlantic herring. Rev. Fish Biol. Fish. 7, 297-329.

Nieberding, C., Morand, S., Libois, R., Michaux, J.R., 2004. A parasite reveals cryptic phylogeographic history of its host. Proc. Biol. Sci. 271, 2559-2568.

Pampoulie, C., Slotte, A., Óskarsson, G.J., Helyar, S.J., Jónsson, Á., Ólafsdóttird, G., Daníelsdóttir, A.K., 2015. Stock structure of Atlantic herring Clupea harengus in the Norwegian Sea and adjacent waters. Mar. Ecol. 522, 219-230.

Parmanne, R., Rechlin, O., Sjöstrand, B., 1994. Status and future of herring and sprat stocks in the Baltic Sea. Dana 10, 29-59.

Polzin, T., Daneschmand, S.V., 2003. On Steiner trees and minimum spanning trees in hypergraphs. Oper. Res. Lett. 31, 12-20.

Reid, J.B., Evans, P.G.H., Northridge, S.P., 2003. Atlas of Cetacean Distribution in Northwest European Waters. Joint Nature Conservation Committee, Peterborough.

Reiss, H., Hoarau, G., Dickey-Collas, M., Wolff, W.G., 2009. Genetic population structure of marine fish: mismatch between biological and fisheries management units. Fish Fish. 10, 1467-2979.

Rosenberg, R., Palmén, L.E., 1981. Composition of herring stocks in the SkagerrakKattegat and the relation of these stocks with those of the North Sea and Adjacent waters. Fish. Res. 1, 83-104.

Ruzzante, D.E., Mariani, S., Bekkevold, D., André, C., Mosegaard, H., Clausen, L.A.W., Dahlgren, T.G., Hutchinson, W.F., Hatfield, E.M.C., Torstensen, E., Brigham, J., Simmonds, E.J., Laikre, L., Larsson, L.C., Stet, R.J.M., Ryman, N., Carvalho, G.R., 2006. Biocomplexity in a highly migratory pelagic marine fish Atlantic herring. Proc. R. Soc. Lond. Ser. B 273, 1459-1464.

Ryman, N., Lagercrantz, U., Andersson, L., Chakraborty, R., Rosenberg, R., 1984. Lack of correspondence between genetic and morphologic variability patterns in Atlantic herring. Heredity 53, 687-704.

Schneider, S., Excoffier, L., 1999. Estimation of demographic parameters from the distribution of pairwise differences when the mutation rates vary among sites: application to human mitochondrial DNA. Genetics 152, 1079-1089.

Shaw, P.W., Turan, C., Wright, J.M., O'Connell, M., Carvalho, G.R., 1999. Microsatellite DNA analysis of population structure in Atlantic herring (Clupea harengus), with direct comparison to allozyme and mtDNA RFLP analyses. Heredity 83, 490-499.

Slotte, A., Johannessen, A., 1997. Spawning of Norwegian spring spawning herring (Clupea harengus L.) related to geographical location and population structure. ICES C.M. 17 CC.

Tajima, F., 1989. Statistical method for testing the neutral mutation hypothesis by DNA polymorphism. Genetics 123, 585-595.

Timi, J.T., Mackenzie, K., 2015. Parasites in fisheries and mariculture. Parasitology $142,1-4$.

Toresen, W., Osvedt, O.J., 2000. Variation in abundance of Norwegian spring-spawning herring (Clupea harengus, Clupeidae) throughout the 20th century and the influence of climatic fluctuations. Fish Fish. 1, 231-256.

Ugland, K.I., Strømnes, E., Berland, B., Aspholm, P.E., 2004. Growth, fecundity and sex ratio of adult whaleworm (Anisakis simplex; Nematoda Ascaridoidea Anisakidae) in three whale species from the North-East Atlantic. Parasitol. Res. 92, 484-489.

Wheeler, J.P., Winters, G.E., 1984. Homing of Atlantic herring (Clupea harengus) in Newfoundland waters as indicated by tagging data. Can. J. Fish. Aq. Sci. 41, $108-117$. 